certifying authority needed, and was fortunate to receive, the full and willing co-operation of all participants. Some 824 growers and 93 merchants took part in the production of 53,500 cwt. of British certified seed. With the co-operation of the Seeds Branch of the Ministry of Agriculture, Fisheries and Food, check samples were drawn from most lots of certified seed and have been tested and then grown in plots for verification purposes. The Official Seed Testing Station received a very similar number of samples in the year under review compared with the previous year, but the proportion of cereals to clovers and root and vegetable samples was much greater because of the very different weather conditions experienced in the two years. The number of samples of each variety of cereal received for testing is some indication of the relative popularity in the country as a whole, and this information is summarized in a table. A notable feature is the disappearance from the list of four old-established varieties, Square. head's Master, Wilma, Holdfast and Minister. Among the barley varieties, the proportion of Proctor has further increased. The report refers to a number of building developments, including extension to the main building, a cold store and a new glass house.

\title{
THE COLOMBO PLAN
}

$\mathrm{T}$ HE sixth annual report* of the Consultative Committee for the Colombo Plan for co-operative economic development in south and south-east Asia, as usual, is in three parts. The first includes a general review of economic progress in the area and of the task ahead; the second summarizes the position in individual countries; and the third directs attention to some contributions to economic development made under the Plan and summarizes the contribution of technical assistance in particular.

Further progress in economic development in the area is recorded and the growth of per capita real income appears to have been maintained in spite of balance of payment difficulties and increased internal inflationary pressures. Agricultural production, as well as industrial and mining output, in general, showed an upward trend, but exports did not keep pace with the expansion of imports; prices of some of the main products of the Colombo Plan countries fluctuated, and as a result of these fluctuations and of higher prices of imports, the terms of trade worsened for many countries in the region.

Several countries in the region have now approved development plans, and all are evolving programmes designed to accelerate development. Experience in 1957, however, has emphasized the risk that the pace of development may outrun the availability of resources, and consequently the implementation of development plans should permit re-phasing to match the resources available. Once again, the report stresses the desirability for the countries of the area to pursue policies which serve to attract capital, domestic and external, into development projects and to assure the effective utilization of such capital. A pointed reference is made to the need for consideration of such factors as apprehensions as to the security of investment, difficulties with administrative and financial procedures and restrictions, and uncertainties about the incidence and weight of taxation, all of which could offset the attractions of the region.

Again, the problems of the different countries vary considerably, and accordingly the methods of meeting their needs vary widely also. This is brought out particularly in technical assistance, where some countries need help mainly in the shape of highly qualified missions specially oquipped to deal with the

* Colombo Plan for Co-operative Economic Development in South and South-East Asia. Sixth Annual Report of the Consultative Committee, Saigon, Viet Nam, October 1957. Pp. 166. (Cmnd. 315.)
(London: H.M. Stationery Offce, 1968.) 68. net. planning or implementation of major projects, while others seek quite simple skills. It is important that technical assistance should fit the individual needs of each country, and continuing care is required to ensure that technical resources are not wasted. Continual reference is made in the report to the search by the countries of the area for additional resources, more capital, more equipment, and more managerial and technical skill. Although there are signs of strain in some of the more highly developed as well as in the less-industrialized countries, the situation is not regarded as discouraging, because there are signs that the urgent tasks of development and the raising of living standards are being tackled with speed and energy.

Since 1950, training has been extended to about 13,000 trainees from countries of the area, while about 6,000 experts have been provided by Colombo Plan members and United Nations agencies. Australia alone has contributed $\mathfrak{£ 3 , 4 4 0 , 0 1 9}$ to technical assistance, and during 1956-57 spent $£ 5$ million on capital and technical assistance, including $£ 200,000$ on technical equipment. Another 439 treinees were received and sixty new appointments of technical experts were made, bringing the total in the field in June to sixty-six. Canada's contribution to capital projects and technical assistance amounts to $196 \cdot 7$ million dollars, of which 34.4 million will be for 1957-58, and more than 4 million dollars $(1.4$ million dollars in 1956-57) on technical assistance. Since 1951, 712 fellows and scholars have been trained in Canada, and 201 of these were still there in June 1957, while 100 experts have been sent abroad, of whom 35 are at present carrying out assignments in seven centres. New Zealand's contribution for capital and technical assistance will amount to $£ 7$ million by June 1958 , expenditure on technical assistance totalling $\mathfrak{£ 7 4 4 , 0 0 0}$ by June 30, 1957, under which training had been provided for 459 persons (148 in 1956-57) and 72 New Zealand experts provided (16 in $1956-57)$.

The United Kingdom has since 1951 made available to countries in the area, by way of grants, loans, credits and technical assistance, $£ 92$ million, including $£ 2.7$ million for technical co-operation up to June 30 , 1957, with forward commitments of $£ 1,275,000$. Of this, $£ 862,540$ has been for research and training equipment, with further commitments of another $£ 786,895$. By June 1957, 1,582 trainees had been taken, including 333 from non-Commonwealth coun. tries, and in collaboration with the United Kingdom 
steel industry and the Government of India up to 300 Indian steel workers are to be trained in the United Kingdom for managerial and technical posts at the new steel works at Durgapur. Of 263 experts provided by the United Kingdom, 23 have gone to non-Commonwealth countries. United States Government economic and technical assistance to Colombo Plan countries during the year totalled 900 million dollars, bringing the total since 1950 to more than 3,000 million dollars. During the year, more than 1,000 technicians and students were taken to the United States under the Mutual Security Programme and 500 sent to third countries such as Japan and the Philippines, while about 550 were taken to the United States under the United States International Educational Exchange Programme. Representatives of sixteen nations of the Colombo Plan Consultative Committee met as a working group in Washington to discuss the United States offer of assistance for establishing a regional nuclear centre to serve the needs of the participating countries.

Summarizing the contribution made by technical assistance, the report recognizes that the world scarcity of technical man-power must limit the supply available for the Colombo Plan. By June 30, 1957, expenditure on technical assistance was more than $£ 8$ million, including $£ 1.8$ million on equipment, and 1,858 persons were receiving training, although the number of new training places declined from 1,552 to 1,395 . At the end of the year about 1,400 experts were assigned to countries of the area. Stress is laid on the scope for help from outside the area in developing adequate training institutions, although success depends primarily on the initiative of the institutions themselves, and also on the encouraging increase in the number of countries in the region now providing training places to other countries in the region (Ceylon, India, Indonesia, Malaya, Pakistan, Thailand and Singapore) as against three countries in the previous year. The technique of team work is being used to an increasing extent and within the United States programme some thirty contracts have been arranged with universities of countries within the area to help them develop curricula, teaching methods and research facilities as well as adequate laboratories and libraries.

\title{
INTERACTION OF FORMALDEHYDE AND TETRAHYDROFOLIC ACID AND ITS RELATION TO THE ENZYMIC SYNTHESIS OF SERINE
}

\author{
By DR. R. L. BLAKLEY \\ Department of Biochemistry, John Curtin School of Medical Research, Australian National \\ University, Canberra
}

\begin{abstract}
$\mathrm{T}$ HE reaction between glycine and formaldehyde to form serine in the presence of an enzyme from liver $\mathbf{r}^{\mathbf{1}}$ requires, as a co-factor, tetrahydrofolic acid $\left(\mathrm{FH}_{4}, \mathrm{I}\right)$, which is believed to act by forming a reactive complex with formaldehyde. The structure of the 'active formaldehyde' was first postulated as $\mathrm{N}^{5}, \mathrm{~N}^{10}$. methylene $\mathrm{FH}_{4}$ (III) in $1954^{1}$, although $\mathrm{N}^{5}$-hydroxymethylFH $_{4}$ (II) is also a possible structure ${ }^{2}$. Formaldehyde is bound strongly by $1: 2$-diamines with the formation of bridged structures. Thus it was demonstrated that $N, N^{\prime}$-diphenylethylenediamine reacts readily with formaldehyde to give a stable cyclic product $^{3}$. It might be expected, therefore, that $\mathrm{FH}_{4}$, which is also a $1: 2$-diamine, would react with formaldehyde to give III, and that this compound would be stabilized to oxygen by the presence of the firmly bound methylene bridge. Although the product of formaldehyde reaction with $\mathrm{FH}_{4}$ was found to be somewhat more stable than $\mathrm{FH}_{4}$ itself, it was nevertheless very sensitive to oxygen, for in aqueous solution it rapidly lost coenzyme activity when shaken under airs. This sensitivity to oxygen has been confirmed by spectrophotometric studies. When a solution of $\mathrm{FH}_{4}$ is diluted with phosphate buffer $\left(p \mathrm{H} \mathrm{7.2)}\right.$ to a concentration of $5 \times 10^{-5} M$ the spectrum changes within a few minutes from that of $\mathrm{FH}_{4}\left(\lambda_{\max } 298 m \mu\right.$ ) to that of oxidized products with $\lambda_{\text {max. }}$ at shorter wave-lengths (finally $275 \mathrm{~m} \mu$ ). If the diluent contains formaldehyde the rate of change due to oxidation is less, but even in the presence of $10^{-3} M$ formaldehyde it is about 3 per cent of that occurring in absence of formaldehyde. In this laboratory, paper chromatography of reaction mixtures has yielded no
\end{abstract}

clear separation of a product with $R_{F}$ different from that of $\mathrm{FH}_{4}$ as reported by others".

These results were at first interpreted as indicating that II must be the structure of the product, and that it must readily dissociate $e^{3,5}$. Investigation of the binding of formaldehyde labelled with carbon-14 by $\mathrm{FH}_{4}$ and related hydropteridines indicated that approximately one molecular proportion of formaldehyde was bound by $\mathrm{FH}_{4}$, smaller amounts by $\mathrm{N}^{10}$. formylFH $\mathrm{H}_{4}$ and 2-amino-4-hydroxy-6-methyltetrahydropteridine and a negligible amount by leucovorin ${ }^{5}$. These results have been confirmed and extended by determination of the formaldehyde concentration in equilibrium with known concentrations of hydropteridines. Since tetrahydropteridine is rather unstable, tetrahydroquinoxaline, a close

Table 1. Approximatz Dissociation Constants fror the Produots FORMED BY THE RRAOTION OF FORMALDEHYDE WTTH HYDROFORMED BY THE REAOTION OF FORMALDEHYDE WIT
PTIRIDINES AND TETRAHYDROQUINOXATINE

\begin{tabular}{|c|c|c|}
\hline & Base & $\begin{array}{c}\text { Dissociation } \\
\text { constant of } \\
\text { product }= \\
{\left[\frac{\text { [CHO] [base] }}{\text { [product] }}\right.}\end{array}$ \\
\hline Group $A$ & FH, & 0.0004 \\
\hline Group $B$ & $\begin{array}{l}\mathrm{FH}_{8} \\
\mathrm{~N}^{10} \text {-formylFH, } \\
\mathrm{N}^{10} \text {-methylFH, } \\
\text { 2-Amino-4-hydroxy-6-methyltetra- } \\
\text { hydropteridine } \\
\text { 4-Hydroxy-6-methyltetrahydropteridine } \\
\text { Tetrahydroquinozaline }\end{array}$ & $\begin{array}{l}0.01 \\
0.01 \\
0.03 \\
0.04 \\
0.04 \\
0.01\end{array}$ \\
\hline$\overline{\text { Group } C}$ & $\begin{array}{l}\mathrm{N}^{8} \text {-formylFH, (leucovorin) } \\
\mathrm{N}^{8} \text {-formyl-4-hydroxy-6-methyltetra- } \\
\text { hydropteridine }\end{array}$ & $\begin{array}{l}0.41 \\
0.45\end{array}$ \\
\hline
\end{tabular}

